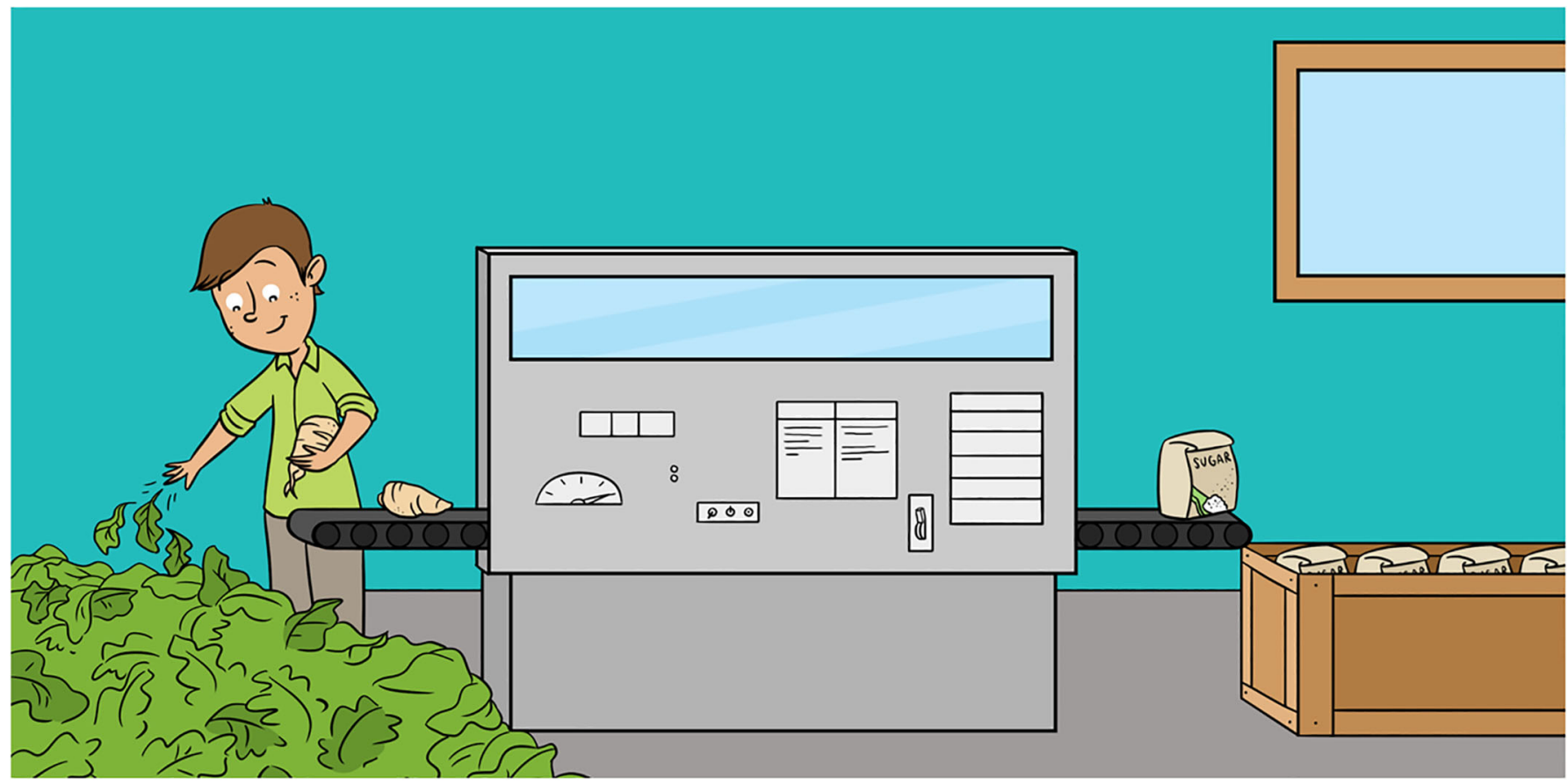

\title{
HOW TABLE SUGAR IS PRODUCED FROM SUGAR BEETS
}

\author{
Matheus Thomas Kuska ${ }^{1 *}$, Sabine von Tiedemann ${ }^{2}$ and Anne-Katrin Mahlein ${ }^{2}$ \\ ${ }^{1}$ Landwirtschaftskammer Nordrhein-Westfalen, Pflanzenschutzdienst, Cologne, Germany \\ ${ }^{2}$ Institute of Sugar Beet Research (IfZ), Göttingen, Germany
}

YOUNG REVIEWER:

NICOLAS

AGE: 9
Plants produce sugar and oxygen in a process called photosynthesis, by using sunlight, water, and carbon dioxide. This is an important process on Earth, since it removes carbon dioxide from the air and provides food for us. Photosynthesis happens in small compartments within the plant cells, called chloroplasts. In a two-step process, plants obtain chemical energy from sunlight. The collected energy is used in a second reaction to produce the sugar glucose. Glucose is combined with fructose, which is fruit sugar, to create sucrose, our well-known table sugar. Sugar beets take $\sim 7$ months to grow and provide $\sim 32 \%$ of the world's table sugar production. As they grow, they must be protected from weeds and diseases. Once they have grown sufficiently, the sugar beets can be harvested and processed in a sugar factory to obtain table sugar. 


\section{PHOTOSYNTHESIS}

The process green plants use to produce energy, in the form of sugar, from sunlight, water, and carbon dioxide.

Table 1

Some forms of carbohydrates in plants.

\section{SUGAR IS PRODUCED BY PLANTS}

A dessert after lunch or chocolate from our grandparents makes us smile. This is because our brains demand one of the ingredients in these sweet foods. We are talking about table sugar, which is also called sucrose. Sucrose is made from two simpler sugars: glucose and fructose. But where does glucose come from? In contrast to humans and other animals, plants can produce glucose through a process known as photosynthesis. The green parts of plants use sunlight, water, and the gas carbon dioxide from the air to produce glucose and oxygen. In doing so, the plants produce energy and ensure that we can breathe fresh, oxygen-rich air. But how do plants themselves benefit from photosynthesis and the production of glucose? Glucose can be used as a chemical building block and as an energy supplier. Plants use glucose to live and grow. For both plants and humans, glucose is like the fuel for a machine.

Plants produce sugar in their leaves, but these leaves do not taste sweet. That is because the sugar does not remain in the leaves. Plants use sugar to grow, and it may also be transported to the roots, seeds, stalks, or fruits for storage. We learnt already that sugar may exist as simple sugars, like glucose or fructose, or as a double sugar, like sucrose. But there are also sugars in which thousands of sugar molecules are linked together to form an enormous unit, like starch. All these different sugars are a type of nutrients called carbohydrates (Table 1).

Many plants store their sugar in the form of starch, like potatoes. Others store sugar in the form of fructose or glucose in their fruits, like apples and oranges. Some plants store high concentrations of sucrose. High-sucrose plants are cultivated for the table sugar we use to make our delicious sweets. Worldwide, sugar beets and sugar cane are the main crops that produce sugar. Sugar cane needs warm temperatures $\left(25-30^{\circ} \mathrm{C}\right)$ to grow, so this crop is grown in subtropical and tropical regions, like Brazil and India. Today, sugar beets are the main crop for sugar production in temperate climates $\left(15-25^{\circ} \mathrm{C}\right)$, especially in Western, Central, and Eastern Europe, as well as in the United States, China, and Japan.

\begin{tabular}{lll}
\hline Common name & Scientific name & Can be found in \\
\hline Dextrose & Glucose & Fruits \\
Fruit sugar & Fructose & Fruits \\
Table sugar & Sucrose & Sugar beet, sugar cane \\
Starch & Amylum & Potatoes \\
Cellulose & Cellulose & Plant cell walls \\
\hline
\end{tabular}

Table 1 
Figure 1

A simplified

illustration of

photosynthesis. Inside

the chloroplasts within

leaves, light, water

$\left(\mathrm{H}_{2} \mathrm{O}\right)$, and carbon

dioxide $\left(\mathrm{CO}_{2}\right)$ are

transformed into

energy and sugar

(glucose). Using water,

sunlight is converted

into energy-storing

molecules within the

plant cells. The energy

from these molecules

is then used to create

glucose from $\mathrm{CO}_{2}$.

\section{CHLOROPLAST}

Small structures inside leaves that conduct photosynthesis.

\section{CHLOROPHYLL}

Pigments inside chloroplasts that absorb the light energy from sunlight.

\section{Photosynthesis leaf with chloroplast}

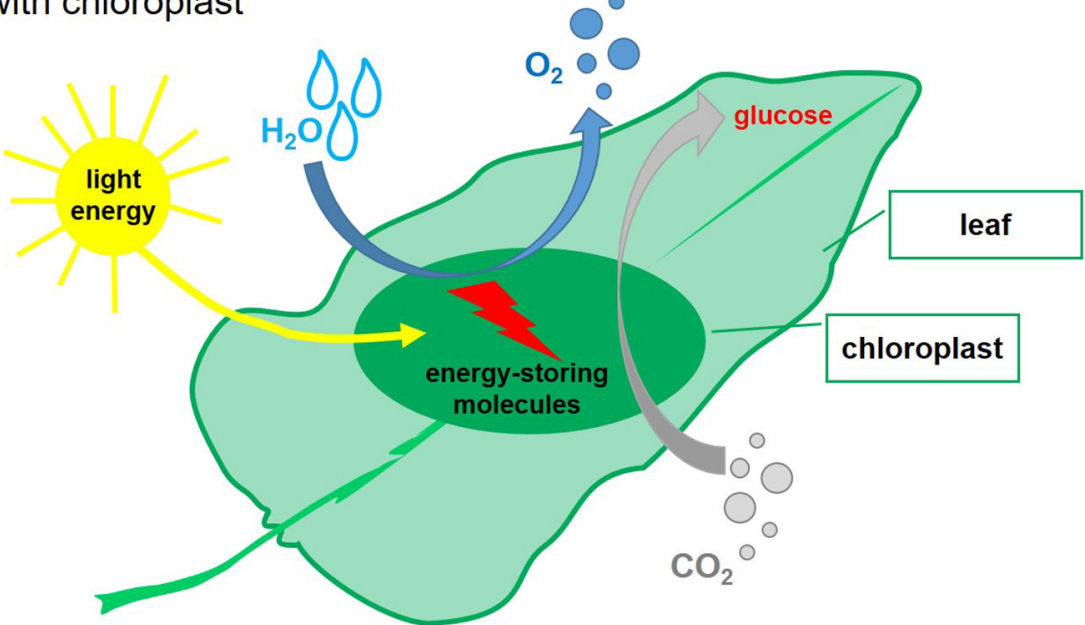

Figure 1

\section{LIGHT, CARBON DIOXIDE, AND WATER: THE SOURCES OF ENERGY AND SWEETNESS}

For photosynthesis, the green parts of plants are important. Leaves are green because they contain structures called chloroplasts, which have a green pigment, called chlorophyll (Figure 1). Photosynthesis has two main steps. In the first step, sunlight shines on the leaves and the light energy is collected by the chlorophyll in the chloroplasts. The collected light energy gets converted into chemical energy and stored in energy-storing molecules. Oxygen is also produced during this process, and is released by the plants [1]. In the second step of photosynthesis, carbon dioxide from the air enters the leaves through very small openings. Using the previously stored chemical energy, the chloroplasts convert carbon dioxide into glucose [1]. Fructose is also produced during this step. Glucose is then combined with fructose to create sucrose.

\section{WHAT IS A SUGAR BEET?}

People have always found substances to sweeten food. But, in cool climates, sugar was luxury product for many years. In 1747, the German chemist Andreas Sigismund Marggraf discovered that beets produce the same sugar as sugar cane. His student developed a technical process to extract the sugar from beets. The first sugar factory became operational in 1802. Soon, many sugar factories were built all over Europe.

The sugar beet plant (called Beta vulgaris in Latin) has bright green leaves in a rosette pattern and a cone-shaped, white, fleshy root (Figure 2). The beet root is the storage organ, containing 75\% water, $\sim 20 \%$ sugar, and structural components that are called pulp. 
Figure 2

Fully developed sugar beet plant. The below-ground part is the storage organ, called the taproot, which has hairy roots to absorb water and nutrients. The above-ground part consists of the foliage, which contains numerous leaves arranged in a rosette-like pattern.

\section{PESTICIDES}

Substances used to protect crops against weeds, fungal pathogens, and pests.

\section{PILL}

Sugar beet seed, which is coated with a layer of different substances, mainly to protect the seedling against diseases and pests.

\section{COTYLEDON}

The first two leaves that emerge from the seed after sowing.

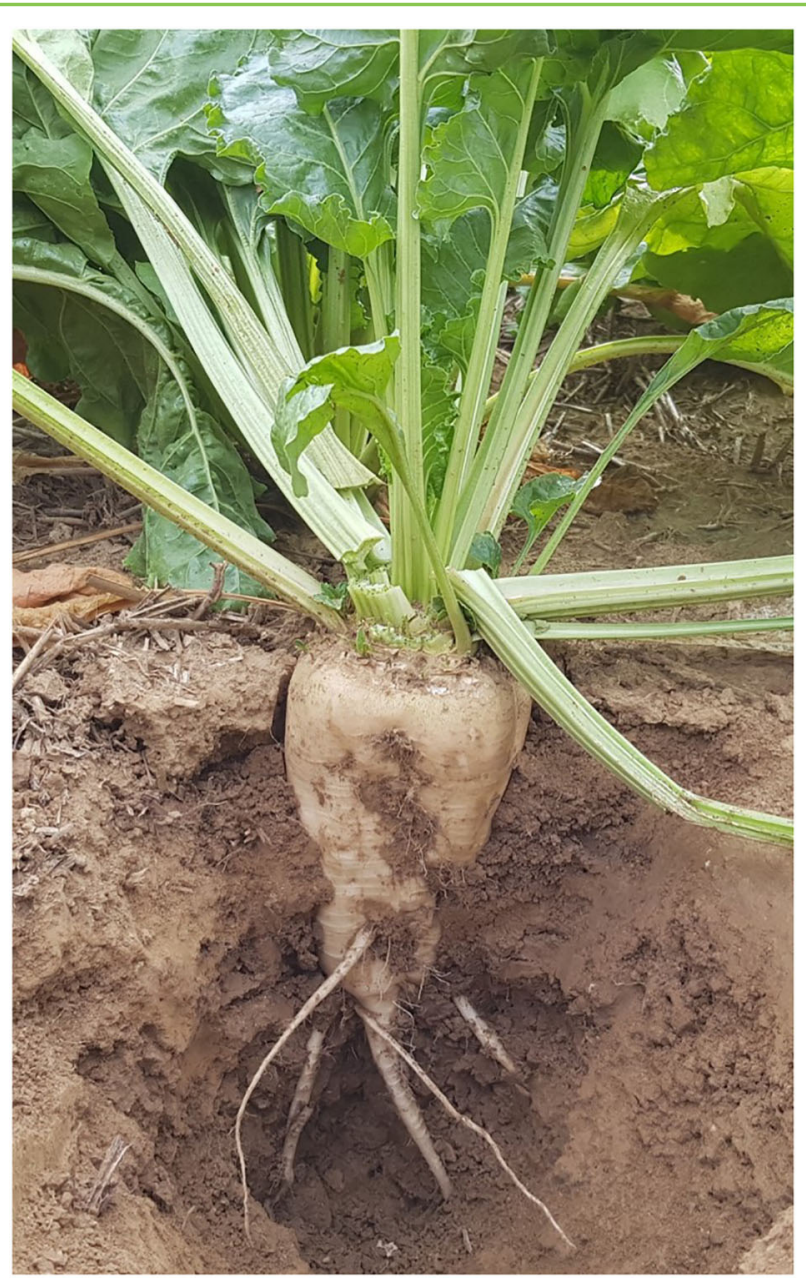

Figure 2

\section{CULTIVATION OF SUGAR BEETS}

Cultivation of crops may look simple, but this is not true if you want to grow crops large enough to feed many people. Let us have a look at how sugar beets are cultivated (Figure 3). Our journey starts with the sugar beet seed. The seeds are sown once the soil has warmed up, normally in March/April. One sugar beet seed naturally develops into many plants. Until the 1970s, the unnecessary plants needed to be removed by hand so that the beets were not too crowded, which was strenuous and time-consuming work. Then, plant breeders had a breakthrough and introduced seeds that produce only a single seedling. Seed breeders that make sugar beet seeds coat the seeds with pesticides that protect seedlings against diseases and pests. The coated sugar beet seed is called the pill, and the pills often have different colors depending on the breeder (Figure 3A).

When the seeds germinate, small roots and two seed leaves, called cotyledons, emerge (Figure $3 \mathrm{~B}$ ). From this point on, the young sugar beet plant must be protected from weeds, because weeds compete 
Figure 3

Sugar beet cultivation. (A) In spring, sugar beet seeds (shown here as pills, which are seeds coated mainly with substances to protect the seedling against diseases and pests) are sown in a row. $(\mathbf{B}, \mathbf{C})$ Young sugar beets seedlings emerge and grow. (D) When nine or more leaves have unfolded, a taproot forms and grows underground to store the sugar. During this "growth period," particularly fungal parasites must be controlled, which can inhibit the photosynthesis. (E) In Western and Central Europe, the beets are harvested starting in September. (F) Beets are stored as a pile called a clamp on the field border, until they are brought to a factory for sugar extraction. Along the bottom, you can see the steps of sugar beet cultivation for sugar production and the time span, which is really important to protect sugar beets against, weed, insects, and fungal parasites.

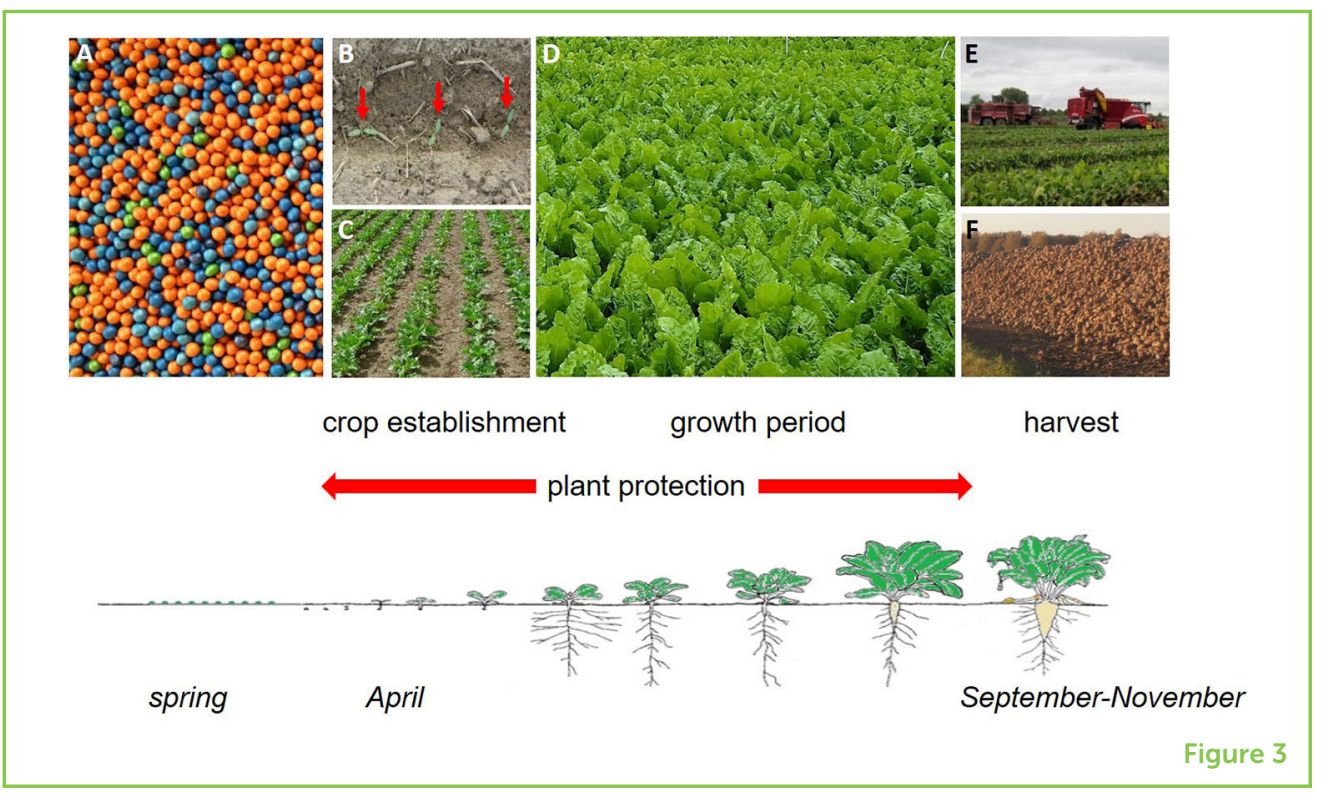

for sunlight and soil nutrients. Farmers can control the weeds with a hoe or can use herbicides, which are chemicals that kill the weeds. If the farmer does not control the weeds, the small beets will be overtaken and the crop yield can be reduced by up to $80 \%$ [2]. Beets do not only have to fight against competing weeds. They are also attacked by insects. Beet-attacking insects can be separated into two groups: those that directly damage the plant and those that transmit viral diseases. The green peach aphid (Myzus persicae), for example, can transmit a virus causing a yellowing of the sugar beet leaves, which inhibits photosynthesis and reduces sugar production.

\section{BEETS MUST BE PROTECTED AGAINST FUNGAL DISEASES}

After the sugar beet plant has developed nine or more leaves, the "beet" or underground storage organ, is formed. Sucrose produced in the leaves is stored in the beet. The sunnier the summer, the more sugar can be produced via photosynthesis. During this time, the leaves must be protected against fungal diseases, because only healthy leaves can perform photosynthesis. The most widespread and destructive disease of sugar beet leaves is caused by a fungus with the Latin name Cercospora beticola. At first, only small circular dark spots with a reddish border are visible, but the fungus produces a toxic substance that destroys the leaf tissue and ends up killing large areas or even whole leaves. The fungus uses the dead tissue as source of nutrition [3]. The disease can be reduced by cultivating sugar beets only every 3 years and growing other plants, like cereals, in the years in between [3]. This technique is called crop rotation. Farmers can also use new Cercospora-tolerant sugar beet varieties, which can better tolerate the disease [3]. If the fungus has already attacked the sugar beets severely, fungicides, which are chemical substances that protect plants 


\section{BEET CLAMP}

Pile of collected and cleaned sugar beets, without leaves, normally on the field border. against fungal infestations, can be sprayed on the plants. Researchers are investigating new technologies to reduce the use of fungicides. For example, by using special cameras and computer systems, the plant diseases can be predicted much earlier than they can by the naked eye, and farmers can use fungicides in a more targeted way [4]. This is also important to protect beneficial animals, which have a habitat in sugar beet fields, like the peewit, other birds nesting on the ground, hares or rabbits and insects like beetles, such as the lady beetle. However, the sugar beet is not flowering when grown for sugar production, thus sugar beet fields are not attractive to honey, wild or bumble bees.

\section{HARVESTING AND EXTRACTING THE SUGAR}

In the autumn, when the plants are done growing, the sugar beet harvest starts. The leaves of the sugar beets are removed and the beets are lifted from the soil by beet harvesters, many of which can harvest six rows simultaneously (Figure $3 \mathrm{E}$ ). The leaves remain on the field as a natural fertilizer. The sugar beets are collected in a pile, called a beet clamp (Figure 3F), where they await processing. The sugar beets are gradually harvested and transported to factories so that the factories can continuously receive and process sugar beets during this time. In the factories, sugar is extracted from the beets using water, lime, heat, and knowledge of physics. On average, six to seven sugar beets are needed to produce $1 \mathrm{~kg}$ sugar ( $2.2 \mathrm{lbs})$, which is a crop area of about $1 \mathrm{~m}^{2}$.

Today, nearly all components of the sugar beet plants are used within a sustainable, closed circle. In addition to sugar, other products made from sugar beet include animal feed, bioethanol and biogas.

\section{WHAT DID WE LEARN?}

In this article, you learned a lot about sugar beets: how they grow, how they produce sugar, the pests and diseases they face, and how they are harvested. Sugar beet cultivation is extremely important because, it provides $\sim 32 \%$ of the world's table sugar production and it is the only high-sucrose crop, which can be cultivated in temperate regions.

\section{ACKNOWLEDGMENTS}

The authors thank Maximilian Müllender for careful proofreading of the manuscript and helpful comments. 


\section{REFERENCES}

1. Eberhard, S., Finazzi, G., and Wollman, F.-A. 2008. The dynamics of photosynthesis. Annu. Rev. Genet. 42:463-515. doi: 10.1146/annurev.genet.42. 110807.091452

2. Cousens, R. 1985. A simple model relating yield loss to weed density. Ann. Appl. Biol. 107:239-52. doi: 10.1111/j.1744-7348.1985.tb01567.x

3. Weiland, J., and Koch, G. 2004. Sugarbeet leaf spot disease (Cercospora beticola Sacc.). Mol. Plant Pathol. 5:157-66. doi: 10.1111/j.1364-3703.2004.00218.x

4. Mahlein, A.-K., Kuska, M. T., Behmann, J., Polder, G., and Walter, A. 2018. Hyperspectral sensors and imaging technologies in phytopathology: state of the art. Ann. Rev. Phytopathol. 56:535-58. doi: 10.1146/annurev-phyto-080417-0 50100

SUBMITTED: 10 January 2020; ACCEPTED: 14 July 2020;

PUBLISHED ONLINE: 21 August 2020.

EDITED BY: Dominik K. Großkinsky, Austrian Institute of Technology (AIT), Austria

CITATION: Kuska MT, von Tiedemann S, Mahlein A-K (2020) How Table Sugar Is Produced From Sugar Beets. Front. Young Minds 8:108. doi: 10.3389/frym.2020. 00108

CONFLICT OF INTEREST: The authors declare that the research was conducted in the absence of any commercial or financial relationships that could be construed as a potential conflict of interest.

COPYRIGHT @ 2020 Kuska, von Tiedemann and Mahlein. This is an open-access article distributed under the terms of the Creative Commons Attribution License (CC BY). The use, distribution or reproduction in other forums is permitted, provided the original author(s) and the copyright owner(s) are credited and that the original publication in this journal is cited, in accordance with accepted academic practice. No use, distribution or reproduction is permitted which does not comply with these terms.

\section{YOUNG REVIEWER}

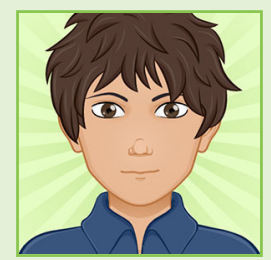

\section{NICOLAS, AGE: 9}

I grew up in Spain but now I live in Vienna. I can speak in German, English, and Spanish. My favorite subject at school is Maths and my favorite sport is football (soccer for Americans).

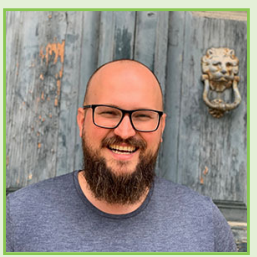

\section{AUTHORS}

\section{MATHEUS THOMAS KUSKA}

As a passionate biologist specializing in plants and microbes, I particularly enjoy studying how they live together, to improve our knowledge for sustainable plant protection and agriculture. Therefore, I use modern machines, cameras and computers to analyze plant diseases and pests in greenhouses and on the field. In 


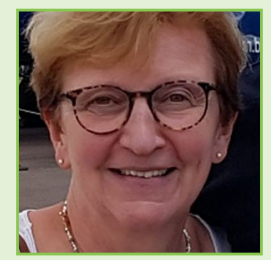

my current position, at the North Rhine-Westphalia Chamber of Agriculture, my team and I study sustainable agriculture, to secure a sufficient crop production with the lowest environmental stress as possible. We also run an advisory service, to make our results available to farmers. *matheus.kuska@lwk.nrw.de

\section{SABINE VON TIEDEMANN}

As an agronomist, I have dealt with forecasting models in cereal cultivation, with plant pathological questions in viticulture and forestry. Currently, I am working in the field of sugar beet cultivation, at the Institute of Sugar Beet Research, where I also teach scientific writing and enjoy breaking down complex subjects so that students can understand them.

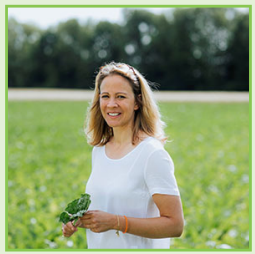

\section{ANNE-KATRIN MAHLEIN}

I study plant-pathogen interactions and ways to visualize complex reactions going on inside plants, with optical sensors and digital technologies. At the Institute of Sugar Beet Research, my team and I are responsible for developing innovative sugar beet cultivation practices. This considers all aspects of sugar beet and table sugar production, like yield and quality forming, and plant diseases and protection. Therefore, we use modern machines, sensors, robots, analyzing tools, field, and laboratory studies. 